\title{
Understanding Between High Potentials and High Performers
}

\author{
Nomahaza Mahadi \\ Azman Hashim International Business School, Universiti Teknologi Malaysia \\ Level 10, Menara Razak, Jalan Sultan Yahya Petra, 54100 Kuala Lumpur, Malaysia \\ E-mail: mahaza@ibs.utm.my
}

Simon Raj A/L Thangaraj

Azman Hashim International Business School, Universiti Teknologi Malaysia Level 10, Menara Razak, Jalan Sultan Yahya Petra, 54100 Kuala Lumpur, Malaysia E-mail: simonraj@gmail.com

\begin{abstract}
Shathees Baskaran
Azman Hashim International Business School, Universiti Teknologi Malaysia Level 10, Menara Razak, Jalan Sultan Yahya Petra, 54100 Kuala Lumpur, Malaysia E-mail: shathees@ibs.utm.my

Nomahaza Mahadi (Corresponding author)

Azman Hashim International Business School, Universiti Teknologi Malaysia Level 10, Menara Razak, Jalan Sultan Yahya Petra, 54100 Kuala Lumpur, Malaysia E-mail: mahaza@ibs.utm.my
\end{abstract}

Received: Aug. 6, 2019 Accepted: Aug. 27, 2019 Online published: Sep. 18, 2019 doi:10.5296/ijhrs.v9i4.15479 URL: https://doi.org/10.5296/ijhrs.v9i4.15479

\section{Abstract}

Talent Management is a comprehensive topic that is gaining attention among the 
organizations and it is one of the utmost vital encounters faced by the organizations worldwide. It is also important to have skilful managers that equipped with knowledge that will navigate the talent. Looking into a raw potential, this conceptual paper evaluates if identifying talent itself is the foremost important step in the overall process of talent management. When the relationship between these two components is evaluated and established, it gives a better understanding how identifying the best available talent is just as important, if not more compared to developing a less talented individual to take up the role of a leader within that particular organization.

Keywords: talent management, performance, talent identification, workforce, human resource

\section{Introduction}

The efficient talent management is linked to an organizational success as it is related to better organizational performance. Within the business world, high performance is a key component that is often prioritized. Indeed, high performance is used as a benchmark in developing talents within a corporation (Lombardo \& Eichinger, 2000). This however is not entirely true in relation of high performance being pitted against high potential. In fact, if an organization fails to differentiate between potential and performance of its employees, identifying talent is going to be a major challenge for them (Meister \& Willyerd, 2010). Unfortunately, many companies end up doing this grave mistake and it can be a rather costly experience from business point of view. An example of this can be viewed from a sales industry scenario. Sales representatives and sales manager are both vital cogs in maintaining a smooth flow of sales for a particular company. Both can turn out to be high performing employees but their potential with regards to sales, as a whole will differ. In a conventional system, when a sales manager position becomes vacant, the top most performing sales representative if often promoted to take up the position (Catherine, 2015). This however might not be the wisest decision, as he/she despite being the top most performing sales personal could lack in managerial skill and do not possess talent in management. This can turn out to be a costly error for the company as they might lose a highly sales generating talent who struggles making the transition to management, which he might be severely lacking.

In fact, a naturally talented manager with much leadership potential might actually be already part of the workforce within the company (Ready, Conger \& Hill, 2010). However, for various reasons that include seniority-based promotion, this talent might not be identified. Often, such a scenario leads to frustration due to feeling of undervalued and lack of job satisfaction, leading to that personal leaving the company in search of other career openings that might utilize his talent (Boudreau, \& Ramstad, 2005). This is a rather unfortunate scenario that takes place in many organizations and it has negative implications both for the firm in terms of business turnover and for its employee in terms of morale bitterness.

Therefore, detecting both high potentials and high performers of a corporation is equally vital for its business growth (MacRae \& Furnham, 2014). In this paper, we will look into dissecting these two factors, with more focus directed towards talent identification, which is 
very often overlooked compared to high performance development in the overall talent management program of any given firm (Lepak \& Snell, 1999). This conceptual paper will be scrutinized from three perspectives. The first part will be on identifying both the factors mentioned above, the second looks into assessing potential against high performance and the final section explore the possible strategies for talent identification.

\section{Identifying High Potentials and High Performers}

Performance and potential are interlinked components within the ever-advancing business world. In reality, with the advancement of technology, having high performance alone without having high potential might not suffice (Corporate Leadership Council, 2005). According to talent management and psychometrics expert (Cassie, 2014), employees have a combination of both potential and performance capacity. The degree to which they possess this however differs from individual to individual. It is therefore vital for the administrative body of a corporation to differentiate between them, as it will allow utilization as well as retention of personals that excel in either one or ideally in both of them.

\subsection{High Potentials}

It is generally agreeable that employees are one of the most important assets of any industry (McDonnell, 2011). In view of that, high potential workforce can be considered to be the greatest asset of any leading industry player. Previous studies found that a high potential employee is twice as valuable to that company in comparison with the other workers (Lombardo \& Eichinger, 2000). For instance revenue and profit growth is twice higher for an organization with stronger leadership capabilities (Bracken, Timmreck \& Church, 2001). The question that needs to be explored is why is that so? What is so special about high potential individuals?

High potential employees can be described as a possibility of individuals becoming something more than what he is currently (Silzer and Church, 2010). In addition, they possess critical thinking abilities and promptly are able to handle tough situations arising from varying types of people. In a nutshell, high potential employees with the right work attitude are those who are able to operate effectively in almost anything that they set their foot on. They have the capability to achieve significantly much more if their talent is identified and subsequently placed in a suitable talent management program to guide them towards their career enhancement (Meister \& Willyerd, 2010; Brian, 2016).

The high potential employees despite being much wanted are generally low in supply (Penny, 2004). The challenge lies with identifying these high potential individuals, who can even come from a low ranking work hierarchy. There are two distinct reasons behind this. The first is due to high potentials are so easily blinded by high performance. An upraised performance is so easily visible externally and can overwhelm potential related attributes such as mental, learning and change agility (Nancy \& Michael, 2016). The second challenge lies with the attending manager, if he knows what are the components to assess while evaluating potential. Very few managers are equipped with tools for identifying high potential and to do competency evaluation of the employee. Hence, often the primary cynosure is directed 
towards performance with little focus on potential recognition (Nancy \& Michael, 2016; Pratch \& Levinson, 2002).

Experience, behavioral factor, expertise and previous performance are elements that are looked into while identifying talent (Pfeffer, 1998). This however does not necessarily provide information on future potential and capabilities of any given worker. Thus, in the overall task of talent identification, a key step would be in focusing on the potential of that employee (Byham, Smith \& Paese, 2002; Lombardo \& Eichinger, 2000). A future looking viewpoint is required in evaluating employees' potential. Analysis into their aspirations along with evaluating their skills and competencies are the initial steps in assessing if an employee has the potential to undertake much complex and larger responsibilities within their organization (Tierney \& Farmer, 2017).

\subsection{High Performers}

Within any organization, high performers generally are the standouts and their difference from the rest is enormous. They constantly out-perform expectations and due to their proven track record, generally are the most likely choice of the management team when confronted with complicated projects and have deadlines to catch up (Brian, 2016). They are considered immense at their job due to their accomplishments, greater communicating skills, superior organizing and planning capabilities, better ability to adapt to change and sharper learning abilities (Veroen, 2015). In fact, they show high degree of expertise and competencies which are however limited to their particular given job scope. With regards to their job, they can be functional unaided and autonomously. However, they might be lacking in terms of potential to further enhance themselves at a higher level. As a leader, they recognized for being managerial, technical and functional (Nancy \& Michael, 2016). From a universal viewpoint, certain human resource (HR) practices if embraced will lead to enhanced performances irrespective of the context of the HR training (Penny, 2004). This HR practices includes training on initiatives, personal effectiveness, flexibility, knowledge, teamwork and leadership (Veroen, 2015). Top performers are a great asset to any corporation that they are working for as they generate greater return on investment and lesser turnovers. A core component of effectual leadership is employee performance management. Indeed, studies have shown managers who employ efficient performance management yield superior business outcomes in contrary to those who do not (Elaine et al, 2002). One research showed staff turner was lesser by 50 percent, client satisfaction scoring higher by 10 to 30 percent, employee commitment grades escalating by 40 percent and net profit for organization doubled (Karaevli \& Hall, 2006).

\section{Assessing High Potential Versus High Performance}

Potential versus performance is a large dilemma for any manager in terms of talent management, especially with regards to talent identification. The question that needs to be analyzed is does it really matter whether it is high potential or high performance? Previous findings provide a clue to the answer of this vital question - out of seven high performers; only one is absolutely a high potential employee (Paauwe \& Boselie, 2005). This is a rather alarming figure. Hence, there is a definite need to assess high potential versus high performance. At the middle to higher management level, the capability to function 
seamlessly at a more complex role and take a higher position in the near future is seen as potential (Lewis \& Heckman, 2006; Meister \& Willyerd, 2010). This rationale however does not give us much information regarding the individual fundamentals that contributes to the potential. Likewise, it also does not explain how it adequately differentiates between high performers, who consistently deliver good results and are greatly appreciated by the corporation from high potential individuals, who in addition to produce results also exhibit exemplary behaviors, skills and the required ambition for a greater job.

The reality is each employee possesses potential as well as performance ability in largely varying dimensions. Some might have huge natural potential within them, but not necessarily blessed with good performance (Veroen, 2015). Similarly, some might be lacking in potential but to compensate for it might have extremely high performance level. The ideal situation will be when a manager has an employee with huge potential and a high performance level.

\section{Model of Performance and Potential}

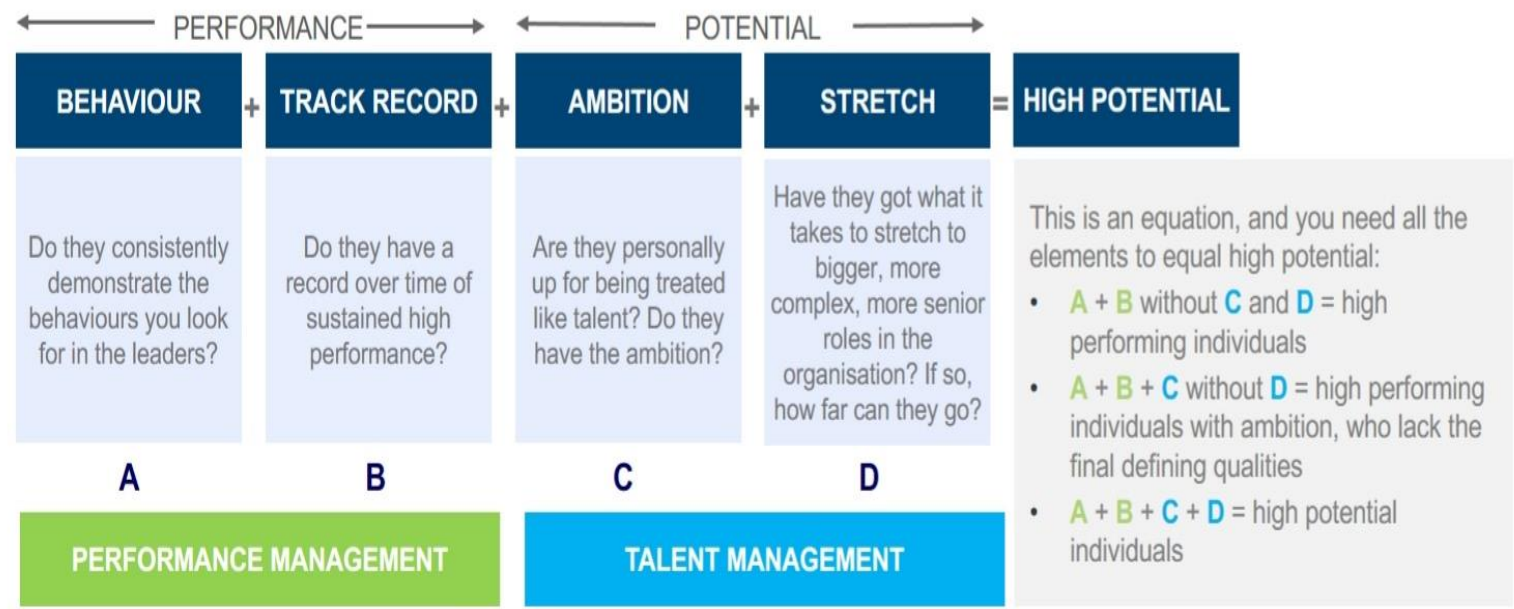

Figure 1. Model of Performance and Potential (Identifying Talent, 2015)

The model of performance and potential as shown above in Figure 1 is a conceptual framework that shows how performance and potential together forms high potential output. Performance management generally consist of two broad component namely being behavior of an employee (component A) and his track record (component B). Component A seeks to explore if the employee consistently demonstrates the behaviors that an organization look for in its leaders. Component B retrospectively identifies if that worker has a record over time of sustained high performance. Collectively, both these components help to analyze the performance level of employees and contribute towards input for talent management (Identifying Talent, 2015).

The second part focuses on potential, which consist of ambition (component C) and 'stretch' element (component D) of an employee. Component $\mathrm{C}$ seeks to see if he/she has the ambition to develop with the organization and if they are personally up for being treated like a talent. Lastly, component D explores the 'stretch' factor, the extent to which an individual can go in their career path. This looks into the part if the worker has what it takes to stretch to take up 
bigger, more complex and senior roles within the corporation. To meet the needs of an organization, the stretch factor needs to be defined and tailored accordingly (Identifying Talent, 2015). To meet their critical talent and specific needs, this model affords flexibility for organizations in using it to pinpoint high potential employees. Employees scoring high on component $\mathrm{A}$ and $\mathrm{B}$ without much component $\mathrm{C}$ and $\mathrm{D}$ only turn out to be high performing individuals. Likewise, high grades on component $\mathrm{A}, \mathrm{B}$ and $\mathrm{C}$ without component $\mathrm{D}$ also only produces high performing individuals with ambition, but those lacking the final defining qualities. An employee who excels in all four components for model of performance and potential will turn out to be a high potential individual.

\section{Developing Strategies for High Potential Talent Identification}

In all fields of economy, there is a war for talent due to the competitive nature of business. As organizations seek to outperform their rivals, it is vital for them to have an effective strategy in detecting high potential talents both from within their ranks and the external talent pool (McCall, Lombardo \& Morrison, 1988; Nancy \& Michael, 2016). Unfortunately, even large corporations do not have a proper process or system in place that allows them to identify individuals with high potential. Hence, they often lose valuable asset in terms of high potential employees. Having a well-established structure in place, this important human resource issue can be tackled (Tierney \& Farmer, 2017). The notion of under-utilization of highly potential employees can be reversed and issues regarding low morale between employee and high turnover rates can also be everted. The best possible scenario would be to have all workers within a corporation as both high performer and highly potential individuals. However, such a scenario is more of a hopeful thought than a reality. The important question that needs to be raised is how we increase the pool of employees toward the right-upper quadrant in the performance - potential matrix. It might not be possible always, but having a talent identification strategy goes a long way in directing organizations towards it. Such a strategy does not come as a one-size-fits-all model (Wood, 1999; Brian, 2016). Corporations looking to establish a strategy for identification of talents with high potential could consider the ensuing principles:

\subsection{Plan for the Future}

As the saying goes, failing to plan is planning to fail. The human resource is a vital department in any organization that needs to carefully plan for the future (Mobley \& Weldon, 2006; Right Management, 2010). They need to foresee the vital yet difficult to fill leadership roles which may become vacant in the near future for that organization. Once these roles have been identified, they need to be followed up with clear exposition for each available position and subsequently prioritization of them. To achieve the human capital needs, the obligations that need to be fulfilled ought to be clearly defined. At times, talents from the internal pool will suffice for such a situation. Such talents should be mentored as a foundation to take up the upcoming roles. However, in other instances, there might be a need to hire from outside of the organization and look for highly potential individuals externally (Ready, Conger \& Hill, 2010). 


\subsection{Definition of High Potential Criteria}

The definition of high potential differs between industries and even among organizations (Wright, Dunford \& Snell, 2001). Therefore, the prerequisites for high potential should be clearly defined by the organization. Terms like potential, performance, readiness and fitness should be made crystal clear in terms of definition. During this defining phase, criteria for high potential with regards to the available job openings within an organization should be described. Regular updating of such a talent identification program must also be carried out to ensure the outcome of the program meets the demands of the organization. In addition to that, a system where the high potential employees can provide a rebuttal evaluation should be in place (Nancy \& Michael, 2016). Once such a system is in place, a training based study program can be formed by the organization for it employees with high potential to cultivate further learning among themselves.

\subsection{Make the High Potential Criteria Measurable}

In the selection process during hiring, it is important for the organization to reduce biases and keep it at a minimum (Identifying Talent, 2015). Forming a metrics for selection of high potential individuals enables the management to decide on the suitability of an applicant to take up the vacant post. In reality, there is no clear measurable criteria yardstick in forming the selection metrics and organizations will need to customize them based on their needs. However, three characteristic attributes are suggested here which a high potential employee should definitely possess to succeed and advance to take up more critical and senior positions within an organization. These three attributes collectively goes hand in hand with the model of performance and potential (Figure 1), which has been discussed earlier.

\subsubsection{Aspiration}

Aspiration is the first and foremost attribute that should be used as measured criteria in determining high potential employee (Ready, Conger \& Hill, 2010). The personal should be evaluated if he/she has the required aspiration to rise up and take up the more senior and responsible roles within a corporation. In other words, an employee should be assessed if they possess vital core career management behaviors along with plain aspiration. This will give a clearer picture if that employee is ready to take the more demanding position and direct those impetuses into further career victories. When compared with the model of performance and potential, aspiration falls within ambition (Component C).

\subsubsection{Ability}

Ability is the second attribute that should be measured in a high potential individual. In simple terms, that worker is assessed if he/she has the ability to be efficient in handling more advanced and responsible roles. This component gauges for leadership capabilities and future managerial abilities that should be present in any high potential talent (Identifying Talent, 2015). Such attribute allows the highly potential worker to have the competencies in succeeding at the more senior position later on. Within the model of performance and potential, ability is compatible with the stretch element (Component D). 
A competent manager and leader is one who will be able to develop an overwhelming vision that is crystal clear and based on constructive ideation (Lewis \& Heckman, 2006), and be able to articulate and exchange information regarding organization goals with her fellow workers and subordinates, which in return inspire them and render guidance. Communication is another aspect that such a personal will need to master and through change, be able to back up others. Finally, a high potential individual with ability is someone who will accomplish objectives and goals for an organization (McCall, Lombardo \& Morrison, 1988).

The ability talents described above are both transformational (leadership) and transactional (managerial) in nature and vital ingredients needed in managers and leaders. Only with such talents, will that personal be able to guarantee on representing a similar objective with the corporation and positive projection, eventually leading to achievement of their key goals.

\subsubsection{Engagement}

The last of the three least attributes that a high potential employee should possess is engagement. In brief, engagement evaluates if the worker is committed to the organization and ready to stay in taking up the demanding roles (Barnett, 2008). This attribute helps in evaluating if the employee foresees the company as the most suitable work place for him to achieve his career goals. In the model of performance and potential, engagement comes under the component of performance management (Component A and B), which is the initial part in the overall step of forming a high potential individual.

One of the best type of dilemmas that a manager would fancy facing is when all his employees are well equipped with aspiration and have high degree of ability. This would make all of them high performers for that organization. However, does this mean such personals will be faithful and stay with the company in the near future? This is when the component of engagement comes into the picture and is vital in the long term for any organization.

Individuals who are likely to leave and keep migrating between corporations have low engagement value (Boudreau \& Ramstad, 2005). Engagement is a core component that forms a truly high potential individual as shown in Figure 1 above. Indeed, it is the most powerful index in showing that a high potential employee will remain loyal in serving an organization. Studies have shown less than $30 \%$ of high potential individuals with low levels of engagement have intentions of staying put with the same organization (The HR guide to identifying high-potentials, 2014). In contrary, around $60 \%$ of those with high degree of engagement show excellent loyalties values and remain with the organization.

\subsection{Identify High Potential}

The final part of developing talent detection strategy is the identification process of high potential individuals. It is already an established fact that high performance which is evaluated through engagement component discussed above in performance management is the initial step in identifying high potential talents. It is however important to remember the statistical data of only one in seven high performers are actually simultaneously also a high potential individual (Corporate Leadership Council, 2005). This demonstrates the importance 
of evaluating aspiration and ability. High potential employees are indeed few in number, hence explains the high demand for them within rival organizations.

\section{Discussion and Conclusion}

High potential employees are a pool of individuals who are very much in demand. Within many organizations, they have a large pool of high performance individuals. However, not all high performing individuals turn out to be highly potential employees (Bracken, Timmreck \& Church, 2001). Indeed, majority of them at their best remain as just high performance workers. On the contrary, high potential employees have the potential to be high performance workers as well. This makes them a valuable asset to any organization. Unfortunately, being of high value makes this group also attractive from a business point of view towards competitors as well.

Often, organizations fail to clearly distinguish between high performance employees from a highly potential talent. This can have a negative impact on both the employee as well or the organization (Byham, Smith \& Paese, 2002). Undetected high-potential employees are often left frustrated as their talent is not fully utilized and often leave to seek greener pastures elsewhere. Meanwhile, organizations have rapid turnovers and lose on possibilities of having significant higher profit when high-potential employees are left untapped.

It is therefore vital for organizations and managers to grasp the relationship between performance and potential (Elaine, Rose, Ryan, \& Michael, 2002). Model of performance and potential clearly explains this relation. Only when this association is understood, organization will be able to plan its strategies in identifying high potential talent from internally from their employees and from external talent pool if the need arises. A strategic plan for such a purpose however varies between organizations and need to be customized based on their needs.

A good strategy for high potential talent identification should be long sighted and has a plan for the future. The involved organization should also clearly define what are the high potential criteria that it is looking for. The high potential criteria should also be easily measurable by both the organization and by other external parties if required. Aspiration, ability and engagement are three core high potential attributes. Managers and organizations as a whole would be wise to look into this core attributes in their search for high potential employees (Karaevli \& Hall, 2006)

Engagement is an important step between both the high potential employee and the organization that the employee's attached to (Barnett, 2008). Employees with high engagement values are more likely to stay put and help in achieving the organization's goals and mission while at the same time fulfill their own aspirations utilizing their abilities. From an organization point of view, developing, retaining and attracting valuable high-potential employees is the major challenge faced in today's competitive business world. It is therefore vital for them to invest in developing the most suitable strategy to obtain and increase their pool of high-potential employees. 


\section{References}

Barnett, R. (2008). Identifying high potential talent.Minneapolis, MN: MDA Leadership Consulting.

Boudreau, J. W., \& Ramstad, P. M. (2005, April). Where' s your pivotal talent? Harvard Business Review, 23-24.

Bracken, D. W., Timmreck, C. W., \& Church, A. H. (Eds.). (2001).The handbook of multisource feedback. San Francisco: Jossey - Bass.

Brian, W. (2016). High Potentials vs. High Performers: A Manager's Guide to Identify, Assess and Develop. Journal of Leadership \& Organizational Studies, 72(4), 27.

Byham, W. C., Smith, A. B., \& Paese, M. J. (2002). Grow your own leaders: How to identify, develop, and retain leadership talent. Upper Saddle River, NJ: Financial -Times Prentice Hall.

Cassie, M. (2014). Accessing the Effectiveness of Authentic Leadership. International Journal of Educational Leadership and Management, 86(11), 24.

Catherine, P. (2015). Identifying High Performers: A Look into Performance Output. Journal of Leadership Education, 28(12), 14.

Corporate Leadership Council. (2005). Realizing the full potential of rising talent (Vol. I). Washington, DC: Corporate Executive Board.

Elaine, D. P., Rose, A. M. H., Ryan, S. O., \& Michael, M. M. (2002). Building a High Performance Culture: A Fresh Look at Performance Management. Retrieved from https://www.shrm.org/hr-today/trends-and-forecasting/special-reports-and-expert-views/Docu ments/High-Performance-Culture.pdf

$\begin{array}{llll}\text { Identifying } & \text { Talent } & \text { (2015). } & \text { Retrieved }\end{array}$ https://www.londonleadershipacademy.nhs.uk/talent-management/identifying-talent

Karaevli, A., \& Hall, D. T. (2006). How career variety promotes the adaptability of managers: a theoretical model. Journal of Vocational Behavior, 69(3), 359-73. https://doi.org/10.1016/j.jvb.2006.05.009

Lepak, D. L., \& Snell, S. A. (1999). The human resource architecture: toward a theory of human capital allocation and development. Academy of Management Review, 24(1), 31-48. https://doi.org/10.5465/amr.1999.1580439

Lewis, R. E., \& Heckman, R. J. (2006). Talent management: a critical review. Human Resources Management Review, 16(2), 139-54. https://doi.org/10.1016/j.hrmr.2006.03.001

Lombardo, M. M., \& Eichinger, R. W. (2000). High potentials as high learners. Human Resource Management, $39(4), \quad 321-30$. https://doi.org/10.1002/1099-050X(200024)39:4<321::AID-HRM4>3.0.CO;2-1

MacRae, I., \& Furnham, A. (2014). High potential: How to spot, manage and develop talent people at work. Bedford Square, London: Bloomsbury Publishing. 
McCall, M. W., Lombardo, M. M., \& Morrison, A. M. (1988). The lessons of experience: How successful executives develop on the job, Free Press, New York, NY.

McDonnell, A. (2011). Still fighting the "war for talent"? Bridging the science versus practice gap. Journal of Business and Psychology, 26(2), 169-173. https://doi.org/10.1007/s10869-011-9220-y

Meister, J. C., \& Willyerd, K. (2010). The 2020 workplace: How innovative companies attract, develop, and keep tomorrow's employees today. New York, NY: HarperCollins.

Mobley, W. H., \& Weldon, E. (Eds.). (2006). Advances in global leadership (Vol. 4). Oxford: JAI Press. https://doi.org/10.1016/S1535-1203(2005)4

Nancy, R. Z., \& Michael, S. (2016). Identifying High Potentials. Journal of Character \& Leadership Development, 56(7).

Paauwe, J., \& Boselie, J. P. P. E. F. (2005). HRM and performance: What's next? Human $\begin{array}{llll}\text { Resource Management } \quad \text { Journal, } & \text { 68-83. }\end{array}$ https://doi.org/10.1111/j.1748-8583.2005.tb00296.x

Penny, T. (2004). High Performance Work Practices. Retrieved from https://www.employment-studies.co.uk/system/files/resources/files/mp36.pdf

Pepermans, R., Vloeberghs, D., \& Perkisas, B. (2003). High potential identification policies: an empirical study among Belgian companies. Journal of Management Development, 22(8), 660-78. https://doi.org/10.1108/02621710310487846

Pfeffer, J. (1998). The Human Equation: Building Profits by Putting People First, Harvard Business School Press

Pratch, L., \& Levinson, H. (2002). Understanding the personality of the executive. In R. Silzer (Ed.), The 21st century executive: Innovative practices for building leadership at the top (pp. 43-76). San Francisco, CA: Josey-Bass.

Ready, D. A., Conger, J. A., \& Hill, L. A. (2010). Are you a high potential? Harvard Business Review, 88(6), 78-84.

Right Management (2010). Reengaging employees in a post-recession world, available at: www.right.com/thought-leadership/articles-and-publications/reengaging-employees-in-a-post -recession-world-best-practices-in- hr.pdf

Silzer, R., \& Church, A. H. (2010). Identifying and assessing high potential talent: Current organizational practices. In R. Silzer \& B. E. Dowell (Eds.), Strategy-driven talent management: A leadership imperative (pp. 213-279). SIOP Professional Practice Series. San Francisco, CA: Jossey-Bass.

The HR guide to identifying high-potentials. (2014). Retrieved from https://www.ucop.edu/human-resources/management-development-program/2014/Donna\%20 Handout.pdf. 


\section{Macrothink}

International Journal of Human Resource Studies

ISSN 2162-3058 2019, Vol. 9, No. 4

Tierney, P., \& Farmer, S. (2017). Creative Self-Efficacy: Its Potential Antecedents and Relationship to Creative Performance. Academy of Management Journal, 45(6). https://doi.org/10.2307/3069429

Veroen, W. (2015). They Are Out There: Finding High Performers. (2016). Journal of Leadership \& Organizational Studies, 77(14).

Wood, S. (1999). 'Human Resource Management and Performance', International Journal of Management Review, I(4), 367-413. https://doi.org/10.1111/1468-2370.00020

Wright, P. M., Dunford, B. B., \& Snell, S. A. (2001). Human resources and the resource based view of the firm. Journal of Management, 27(6), 701-21. https://doi.org/10.1177/014920630102700607

\section{Copyright Disclaimer}

Copyright for this article is retained by the author(s), with first publication rights granted to the journal.

This is an open-access article distributed under the terms and conditions of the Creative Commons Attribution license (http://creativecommons.org/licenses/by/4.0/). 